\title{
The Visible Hand of Economics: Institutional Chance Performance and Sustainable Institutional Development
}

\author{
Selma Sevinç ORHAN, Department of Economics, Faculty of Economics and Administrative Sciences, \\ Pamukkale University, Turkey; e-mail: sorhan@pau.edu.tr
}

\section{Ekonominin Görünür Eli: Kurumsal Değişim Performansı ve Sürdürülebilir Kalkınma}

\begin{abstract}
In this study, there is the analysis of the relationship between economic development and institutionalization process which enhances the institutional change performance of the economy and reduces operation costs. The change and regulation process, which is brought into the price mechanism by mainstream economics through invisible hand metaphor, is discussed within "visible hand" logic by property rights, transaction costs, and contracts economy approach in the NIE approach. By this way, institutions assume the visible hand role in the processes of regulation, preparation and implementation of common mandatory rules and laws in social life which are ignored by mainstream economics. The concept of institution is the product of an interdisciplinary approach providing organizational and behavioral connection between economic theory and economic institutions and giving the economics the lost opportunity to question the political economics.
\end{abstract}

Keywords

New Institutional Economics, New Institutional Economics History, Pluralist Methodology in Economic, Institutional Chance Performance, Sustainable Institutional Development, Governance Structure.

JEL Classification Codes: $\quad$ B25, B52, D23.

\section{$\ddot{\mathbf{O} z}$}

$\mathrm{Bu}$ çalışmada, ekonominin kurumsal değişim performansını artıran ve işleyiş maliyetlerini düşüren kurumsallaşma süreci ile iktisadi kalkınma arasındaki ilişki analiz edilmektedir. Yerleşik iktisat tarafindan görünmez el metaforuyla fiyat mekanizmasına devredilen, değişim ve düzenleme süreci, NIE yaklaşımında mülkiyet hakları, işlem maliyetleri ve sözleşme ekonomileri tarafından "görünür el" mantığıyla tartışılmaktadır. Bu yolla kurumlar yerleşik ekonomi tarafından göz ardı edilen, sosyal yaşamda zorunlu görülen kuralların ve yasaların hazırlanmasında, düzenlenmesinde ve uygulanmasında görünür el rolünü üstlenir. Kurum kavramı, organizasyonel ve davranışsal olarak iktisadi kurumlar ile iktisat kuramı arasındaki bağlantıyı sağlayan, iktisat bilimine kayıp ekonomi politiğini sorgulama fırsatı veren, disiplinlerarası bir yaklaşımın ürünüdür.

Anahtar Sözcükler $\quad$ : Yeni Kurumsal Ekonomiler, Yeni Kurumsal Ekonomi Tarihi, Ekonomide Çoğulcu Metodoloji, Kurumsal Değişim Performansı, Sürdürülebilir Kurumsal Kalkınma, Yönetișim Yapısı. 
Orhan, S.S. (2016), "The Visible Hand of Economics: Institutional Chance Performance and Sustainable Institutional Development", Sosyoekonomi, Vol. 24(29), 73-92.

\section{Institutions, Institutional Change and Institutionalization}

Following the global recession in 2008, money in the global system, competition authority and individual price institution all need to be discussed again within the context of institutional behavior. Organizational institutions of the system such as companies and banks; micro and macro institutions such as price, competition, profits and efficiency; all behavioral institutions affecting preferences under uncertainty savings, consumption and investment trends should be discussed again in terms of economic theory. Over the last decade, the problem of institutionalization which have been emphasized in the reconstruction debate of prominent real and financial system draws attention to the problem of institutionalization in economics. Monetary and financial organizational institutions of the economic system must be formally institutionalized.

Sustainable development issue in the global system is forcing the system to change through economic and political institutions. Global development performance depends on the institutional change performance of the systems. However, mainstream theory focuses on optimization problem among the foreseeable choices and transfers the process of change in economic and political institutions to an invisible hand metaphor. Human behaviors and economic institutions, which are out of the social context, move away from reality as approaching the goal of becoming a universal objective science. The institutional performance issue which was neglected by mainstream economics has to be discussed within the context of the global sustainable development strategy of the economy. In response to the need for real and financial structural reforms such as global financial instabilities caused by global economic policy, financial crises, wave of privatization, tax reform, mainstream economics is not able to manage the scale of institutional regulations and change of the system.

The concept of institution in the New Institutional Economics (NIE) approach, offers a new perspective in the construction of the global system's institutions within the contexts of new institutional historicism and new political economy approaches. Institutions and organizations in the NIE approach are discussed within the contents fed by sociology and social psychology such as order, implicit agreements, contractual relations, individual preferences and culture, conventions, ideology, social capital, confidence, social networks, social change, power distribution, embeddedness and business groups. Institutions comprise interdisciplinary contexts as state of law, legal regulations, political preferences and behaviors, structural reforms, mental models, social representations and social cognition of social sciences such as social psychology, sociology, political science, management science, law and anthropology.

The terminology of the NIE approach can be seen in the works of some economists as Weingast (1987) The Management Organization Theory, Levi $(1988,2002)$ The Theory of The State, Keohone (1984) The Theory of International Organizations, Keohone, Weingast, Noe, Hollad and Taylor, The Theory of Rational Choice Models and Institutionalization. Institutionalism in political economy is used within the contexts of 
either "intrinsic historical institutionalism" or "extrinsic bounded rationality" depending on the rational choices to be internal or external. In this way, institutions will contribute to the processes of regulation, preparation and implementation of the rules and laws which are required in social life, but ignored by mainstream economics. In the new institutional sociology institution term was developed under the leadership of H. Clal, H. White, R. Ecoles (1981), M. Granovetter (1985), M. Schwartz, S. Shapiro (1984) and V. Zeliz (1983) and brought into economics literature by Dimagsio and Powel (1991) as well as Brinton and Nee (1998) (Richter, 2005). Institutions are the starting point in the construction of political economy covering the context of human, institution of economy and economics science.

In the NIE approach, R. Coase, O. Williamson and D. North reduce the transaction costs, which rose through bounded rational behavior under uncertainty, by institutionalization. The allocation of property rights is highlighted in the context of regulation debates in the economy, institutional behavior, institutional performance and development within the contract economies and transaction costs approach. The change and regulation requirement attributed to the metaphor of the invisible hand in the mainstream economics is discussed by "visible hand" logic within the NIE approach. In this study, there is the discussion of the relationship between economic development and institutionalization process which enhances the institutional change performance of the economy and reduces operation costs. The visible hand approach disclosed in different ways in the NIE is remarkable in discussing the economics theoretically and institutionally. In this paper for this aim, known as the visible hand metaphor in the NIE approach, the context which covers the relationship of the institutionalization and institutional development process as well as enhances the institutional change performance of the economy is discussed within the microand macro-economic perspectives.

The first of these perspectives is microeconomics that as per R. Coase and O. Williamson secures the contractual and property rights of the organizational institutions in economics such as firms. Thus, within administrative, legal and economic activity context Coase and Williamson discuss the change and regulation process of firms or other voluntary organizations as well as property rights and transaction costs. In the second perspective, D. North and O. Williamson underline the administrative and legal context envisaging effectiveness in the distribution of resources, reducing transaction costs, and where the boundaries between politics and government is defined by the behavioral theories of economics. Hence, the institutionalization process which has increased the development performance through visible hand is discussed.

\section{Microeconomic Perspective in R. Coase and O. Williamson: Organizational Institutions}

In the NIE approach, R. Coase, O. Williamson and D. North reduce the transaction costs, which rose through bounded rational behavior under uncertainty, by institutionalization (Orhan, 2011, 2016a, 2016b). The allocation of property rights is highlighted in the context of regulation debates in the economy, institutional behavior, 
institutional performance and development within the contract economies and transaction costs approach. In the approaches of R. Coase, Williamson and North, institutionalization process is taken in context of institutional regulations issue. One wing of the NIE approach sees institutionalization as an organization experience in the firm size.

However, in mainstream theory, the firm is the function of only neo-classical production. In terms of optimal allocation of resources, there is no market and company separation in the price theory. As per the NIE approach, firms in the firm-scale organized markets make parties confront with each other through long term contracts. Yet, market is an environment where relations are executed by the help of invisible contracts and where the parties don't have to be face to face with each other constantly. As stated by R. Coase, O. Williamson and D. North, contracts made between the parties in organizational change do not show continuity. In economic relations transparency of contract terms reduces the tendency to opportunistic behavior. In institutional environments where the opportunistic behavior is declined by the regulations (the legal regulations minimizing opportunistic behavior tendency between the parties) following contracts can be reviewed.

In the approaches of R. Coase, Williamson and North, institutionalization process is taken in context of institutional regulations issue. One wing of the NIE approach sees institutionalization as an organization experience in the firm size. However, in mainstream theory, the firm is the function of only neo-classical production. The firm is a "black box" in which limited set of input factors of production are transformed into an output. In his "The Nature of the Firm" book R Coase (1937) proposed that competitiveness increases in firm like organized markets. In Coase's approach, the competitiveness of firm depends on the ability to decrease the transaction costs alongside technological superiority it has in production. Coase's theory of the firm sets off from the fact that the system produces legal ground for reducing transaction costs through the firm size institutionalized markets.

Similar to R. Coase's firm theory, Williamson (2000: 602) defines that the firm is not a technical structure of the production function as opposed to the mainstream economics. Firm is a governance structure with the quality of organization. Firms are institutional units that operate the market mechanism where price is determined, the wage negotiations and contracts are prepared and applied. Entrepreneurial firms reduce operation costs by organizing this process well. According to Coase (1937), Williamson $(1975,1985)$, Klein, Crawford and Alchian (1978), Grossman and Hart (1986), Hart and Moore (1990), it is the firm not market where all transactions are organized including at the first place "supply and demand" behavior in economics.

In O. Williamson's Transaction Cost Economics (TCE) approach (1985) the regulation process of rules in distribution and management of private goods between the parties is discussed through the concept of "institutions of governance". In this way, in TCE approach, institutional regulations problem is associated with the theory of the firm. Institutional regulations are governance structures forming the commercial relations between the parties. In a narrow sense, the concept of governance structure means firms and 
other types of organizations, in the broadest sense; it describes the political governance process of economics. Institutionalization on the market is provided only if the process of economic and political governance is under contract. Commercial firms, voluntary organizations without a profit, the functioning of the public bureaucracy and public behavior motivation are discussed in the concept of governance structure. In this way, economic theory defines the structure of long-term contracts and limits and parties of the contracts.

Williamson with reference to contracting economies approach discusses the problem of continuity of social networks (relational contracts) which has been unforeseen between the parties in the long run. In terms of competition, communication network, social prestige, social position and social roles among actors are transferred to economics literature with the concept of "social network". Social position of the actors is priced as a kind of competitive advantage in the market. In supply/demand behavior, adding social positions into social networks by getting mutuality is essential in the development of market strategies protecting reciprocal power balance of the parties.

In accordance with $\mathrm{O}$. Williamson, the firm is an institutional environment where power is dispersed between formal and informal relations providing effective functioning and minimizing transaction costs by contract economies. Though, in real life, the reciprocal pressure between institution of economics and politics affects the transaction costs of markets. High transaction costs in the system generate levels of high inflation and unemployment, low and uneven income distribution, low savings and high indebtedness or unsustainable current deficit and low performance. In economics, decision units institutionalize informal behavior which protects itself through social learning against bad macroeconomic balances.

In the NIE, despite their correspondence with optimization conditions in resource distribution of mainstream theory, property rights and transaction costs approaches, extending from R. Coase to O. Williamson, vary in content of the concept of the institution and in the method followed. The NIE approach is exposed to similar criticism. There is no common attitude against formalist mathematical methods in the NIE approach. Both Coase in his transaction costs and property rights theory and $\mathrm{O}$. Williamson in his the contract and organization theory follow an analysis method other than those the mathematical models. In New Institutional Economics History approach, D. North analyzes historical documents with a simple cliometric technique. Institutional game theory works in a formalist method within stochastic approach in micro and macro institutions of the mainstream economics. Institutional game theories such as Scotter and Shubik model the effects of different institutional structures on the market by working with intensive mathematical models.

Mainstream approach makes parameter estimations using different sets of assumptions, different simulation models and econometric tests. However, the NIE approach follows less formal methodology than mainstream economics and more formal methodology than the OIE (Orginal Institutional Economics) approach. There is difference between the NIE and the OIE on the matter of methodology. NIE is different from the formalism in 
methodological context. Formalism is the subject of criticism in the OIE approach. The method of the OIE approach is informal and rhetoric. The use of mathematical notions is criticized in the OIE approach. As reported by Langlois (1989: 5) one of the central difficulties with the work of early institutionalists is that they wanted an economics with institutions but without theory. Coase states (1984: 230):

"American institutionalists were non theoretical. Without a theory they had nothing to pass on except a mass of descriptive material waiting for a fire".

O. Williamson thinks that Commons' contract approach is a data collection without a theory (Parada, 2002: 43). However, Rutherford claims that (1994: 27), one of the representatives of modern OIE approach, the OIE is criticized from a theoretical perspective. Mitchell and Commons' statistical works were theoretical as much as descriptive. The impression of the OIE approach as a non-theoretical by mainstream economics originates from the OIE approach's rejection of the generally accepted deductive and formalist method. The method of reasoning far from pluralist approach in economics is at the center of all this criticism. In contrast to the formalist methods of mainstream economics, powered by institutionalization debate, the visible hand metaphor forces the market into a formal change through control and regulation as per the OIE and the NIE approaches.

Allan Gruchy (1947) characterized the issue in terms of less formal or holistic perspective of the OIE approach versus the formalism of the mainstream economics. The mainstream theory, integrated with methodological individualist formalism understanding, accepts the rhetoric and holistic method of the OIE approach as non-theoretic. However, influenced by Deweyian instrumentalism or pragmatism, the OIE approach discusses institutions by culturalist approach (society, economy and human) - outside the mainstream formalism. In this sense, the market is not a notion working with institutions, but it is a de facto situation.

\section{Macroeconomic Perspective in D. North and O. Williamson: Governance Structure}

The institutionalization in D. North and O. Williamson's context depends on social cognitive process which is providing the intellectual and behavioral evolution of institutions in economic systems; defining itself, the other and the state in human mental models and shaping the development perspective. As a product of social cognition that defines the relationship of economics, politics and government through legislation, the development perspective of economic institution institutionalizes economic system under the laws (Orhan, 2016b). The process that improves the performance of institutional change of the economy is discussed under the management structure in O. Williamson's approach. With this concept, attention is drawn to the stages of the institutionalization process which improves the performance of institutional change of the economy and reduces the transaction costs. 
Williamson takes positive political theory, which improves the performance of institutional change, as a stage of development level. In Williamson's approach the governance structure that enhances institutional change performance is discussed in both perspectives: the micro-economic perspective organizing the markets and the macroeconomics perspective within the contexts of economics, politics and state. Whereas, as per Coase's analysis, firms are organizations which organize the market in the firm scale and guarantee the property and contract rights by the laws. The supply and demand behavior in firm - scale organized markets is discussed under the legal context of the price mechanism through supervision and regulation process. In Coase's approach, social benefits and costs, born from all market transactions, are expected to be priced among the parties. Without the abandonment of the neoclassical price theory, market environment is recommended which carries social benefits and costs into a legal basis with property rights. By this way, the connection between institutionalization and price theory is established in markets regulating and supervising the economic activity in firm scales and enhancing the performance of institutional change and development of the economy.

In New Institutional Economics History (NIEH) approach, North draws attention to the relationship of social psychology, political and administrative sciences. This need strengthens the reciprocal relationship between law and economics towards becoming an evolutionary science. In political economy, O. Williamson's microeconomic issues and political decision-making processes are discussed as institutional change performance in terms of macro balances of politics and economics within D. North's approach. The distribution problem of power in governance structure and resources allocation brings closer the disciplines of economics and law.

In D. North's NIEH approach (1981, 1990); the concept of "governance structure" is discussed through the contexts of "institutional environment" and "ideology". North draws attention to institutional culture differences in management and production of public goods and organization of the institutional environment by focusing on the formal and informal institutions controlling the behavior of two or more players. The allocation of property rights is highlighted in the context of regulation debates in the economy, institutional behavior, institutional performance and development within the contract economies and transaction costs approach.

The NIE approach expands the context of the aforementioned institutions in mainstream economics. In a sense, through neo-classic means the institutions of capitalist system are built. Zouboulakis believes that (2004: 3) North is criticized for continuing efficiency based procedural individualist methodological attitude of neoclassical methods. North does not go away from neo-classical methodological individualist approach in his culture and ideology discussion. In North's approach, ideology is used within the private and social context with the content affecting the behavioral patterns of all individuals and covering all individuals within the group. Ideology represents the socially constructed concept. In this way, in North's approach, habits, traditions and attitudes will be at the center of economic analysis. North (1990) connects individual action to institutional structure. 
Incentives, detects and forms of thinking are transferred to the individual as a consequence of heritage called culture.

In North's New Institutional Economics History (NIEH) approach, all institutional change processes and operation of institutions is explained alike by the logic of individual preferences. Zouboulakis maintains that, in North 'approach, ideological and intellectual differences between societies and all institutional differences will disappear with common beliefs and value systems. In a sense, in North's approach, institutional change and the operation process difference does not differ from neo-classical analysis. In the NIEH approach, North was criticized by non-universal method and individualistic approach ${ }^{1}$ within economic and social operation maintaining mainstream framework.

In the OIE approach the economic problems are discussed through Dewey's induction theory, while institutional structure, governance structure and state relations in the works of Williamson, North and Eggersson are discussed by the principles of deductive reasoning within methodological individualist behavioral model of mainstream economics. In the NIE approach, institutional changes performance of the market is based on the ontology. However, in the OIE approach, institutional mechanism of the market is supplied from inductive ontology and Deweyan pragmatism. As maintained by Furubotn and Richter (1998: 2) the NIE adds the institutional world which was ignored by neoclassical economists to micro analysis. In a sense, the NIE approach doesn't part with the neo-classical deductive method and works to extend the range of neoclassical economics without rejecting the marginal theory ${ }^{2}$. However, institutional economy always manages to stay in opposition against expansionist tendency of the neo-classical economics (Özveren, 1998: 475).

Ankarloo assumes that (2002: 3), neo-classical content on institutions is inevitable in North's NIEH approach. Individual in North's approach, as neo-classical individual, is someone who looks for optimal solutions for economic relations and makes rational choices in a daily life. North completely rejects the concept of rationality formally, equipping individual with partial and limited computational skills in discussion of institutional change and shares the burden of mainstream paradigm. On the one hand, North tries to get away from rational individual typecasting of neo-classical approach; on the other

As per Field (1981), Hoffman (1989), Ankarloo (2002) and Fine-milonakis (2003), historicism is a universal understanding in D. North's approach. 2500 or 10000 of years ago human life is explained the same incentive structure and in the same system coercive rules. Milonakis-Fine maintains that (2004), there is an ahistorical conception of history in North's approach. By Ankarloo $(2002,23)$ North calls in history in order to show and verify his own theoretical preconceptions, but if needed historicity can be recalled.

2 According to Austrian wing of the NIE approach such as Laglois R. (1989), Hodgson, G. (1993), M. Rudherford (1994, 1995), W. Kasper (1998), M. Streit (1998), Nelson et Sompat (2001) NIE actually draws the boundaries of neo-classical economics. However, T. Eggerttson states that (1990; 67) NIE has never been part of the hard core of neo-classical economics (Dequech, 2002: 29). 
hand, he confines the change process against relative prices to individuals making the optimization calculations.

However, methodological individualistic attitude in North's approach is different from mainstream economics. Individualism which is highlighted in North's approach is an interaction point between individual and social context. His institutional change project is a free and participatory process. Individual is neither a creator of a situation independent from the process of institutionalization, nor a completely product of this context. Individual is a subject who builds the institutional structure and an object built by society. In North's concept of corporate individualism, individual is the one that forms the structure with the set of rational choices which is restricted to structure available (Zouboulakis, 2004: 8).

\section{Obligation of Economics as to be Evolutionary Science: Institutions against the Invisible Hand Metaphor}

In terms of mainstream paradigm, institutions being as invisible hand are the main constraints within the functions of individual behavior. Social life actors voluntarily convert institutional constraints into the rules through internalization (Hodgson, 1993: 5). However, institutions have deeper content rather than being constrained in the NIE approach. Institutions are the manufacturers of social cognition in socio-economic life. As per OIE approach, institutions produce themselves in certain constraints by providing information on their own. Hodgson believes that $\operatorname{cognition}^{3}$ on institutional economics determines the economic behavior in different directions such as informatics, teleological and perceptual. In North's approach, individual is the creator of mental models and the impressionist. North explains institutional change and the regulatory issues by using the concept of culture. North stretches to the context of "continuous cultural development" from mental models 4 developed by sensory cognition and using the concepts borrowed from social psychology. Continuous cultural development is a prerequisite of Veblen's definition for evolutionist economy. Veblen states that economics is not a science of only economic interests.

3 Cognition, Social cognition: is our manner of remembering, analyzing and interpreting of information, and giving meaning through past experiences and cultural values to social world (people and me). (Baron and Byrne, 1997). Cognitive theory works on effects and the topic of how man gets the information about the social world, how he perceives the social area and how he behaves in the social field on the basis of such information (Scheerer, 1954). Social psychology is cognitive.

4 Mental models are dynamic and produced representations for making a causal explanation of a physical phenomenon and that can be mentally set in order to make assumptions about conditions of the physical world (Vosniadau, 1994). Barquero (1995) states that mental models are implicit, incomplete, sloppy, unrelated to the normal information in many areas, but a strong interpretive and predictive tool in the interaction of the individual with the world, and they are kind of powerful information because they are reliable sources of information as they come from the individual's own perceptual and deductional experience. A mental model is not completed, but it continues to grow and develop when new information is added. (Greca \& Moreira, 2000). Mental models as internal descriptions of the individual of the modeled system can be exposed through behavior, speech, written explanations and descriptions. (Gobert \& Buckley, 2000). 
Economics is an evolutionary science theoretically analyzing the cultural change process. Economics must be the science of cumulative ranking of institutions (1898a, 1898b).

Veblen defines the evolutionary economics as a process of cumulative change of institutions with different economic interests affecting continuous cultural development and growth. North says that the basis of growth and development is a constant change of economic interests and institutions. After the 1990s, North discusses the institutionalization process within the context of cultural change rather than efficiency. However, the process of institutional change doesn't withdraw from economic efficiency goal. In Veblen's approach, economics' obligation to be evolutionist science is explained by evolutionary vision which was contributed to economics by institutional change and the regulatory performance.

he invisible hand metaphor protected with formalism, which has given economics spontaneous change and regulation performance and made economy closer to positive sciences, is abandoned the NIE approach. Companies or organizations composed of voluntary organizations in the economy are discussed within the concept of "institution of governance" in the NIE approach. Instead of mainstream formalism, NIE approach makes regulation problems as a prime target by approaching critical realist methodology. Thus, the metaphor of the invisible hand, irreplaceable by liberal approaches, has been abandoned by NIE approach. Instead, there is a place given to institutionalization process which has reduced transaction costs, and to institutions which have enhanced the regulation and change performance of the economy. In a sense, the frame, which has heterodox in essence such as property rights, contract economies, social learning and the institution of governance, replaces the metaphor of the invisible hand in the NIE approach.

In liberal theory, institutional transformation/change process is discussed within the context of economics and law. The change of institutions through public policy and its regulation by law develops in a radical course through reforms or illegal ways. Informal change in institutional structure remains to be quite slow because of its cultural content. In the liberal social theory, various pressure groups shape institutional change through formal rules. In social life, pressure groups protecting special interests shape historical and cultural structure. In a sense, ideology prepares the frame that shapes formal institutions. The performance of the process of institutional regulations depends on the production of market relations in institutional environments within formal and informal set of rules. In liberal theory, the process of institutional change cares about the genesis form of market relations. Liberal theory prioritizes two questions on institutional environment increasing economic performance. The first question: Are formal and informal set of rules, which institutionalize the market behavior, the result of collective action? Or is it the result of spontaneous actions of individual in society? The Second one: if formal and informal rules forming institutional environment are the result of collective action, what is probability of these rules to be shaped by political pressure groups then? 
On the other hand, the process of institutional change ranked as "naive change" or "sophisticated change" in political economy literature. Market rules are accepted as a given between the parties in naive change process. In mainstream economics, institutional change is external variable based on price mechanism. Markets work within in the process of naive change in economics. However, in the process of sophisticated change, market rules are discussed between the parties. State is one of parties in the discussion. Organized interest groups have impact on economic policies and prices. On the other hand, unorganized third parties are the forces of repression determining market rules. For example, the struggles of wage among the unemployed in the labor market, employers and consumers generate inner change channels of economy.

In the NIE approach, the context of institutional change is different from the context envisaged by Hayek and Buchanan for liberal economy. In the NIE literature, the process of institutional change, property rights, transaction costs, contracts economy and in the new institutional economics history approach discussion made by "visible hand" logic. "Invisible hand" metaphor foreseen by Hume, Menger and Hayek continues working in the process of change in the economy with in present day NIE approach. Institutional change is discussed through the concept of structured / constructed order in the NIE approach. According to this, it is not expected the process of institutional change to be realized by "invisible hand" due to law's inability to be perfect in social life. Opportunistic behavior trends develop in all circumstances of social life.

In the economic system, efficiency condition in the allocation of resources depends on the size of informal rules expanding space of legal structure within the system (Furubotn \& Richter, 2005: 29). Institutional change process is discussed within "visible hand" approach by new institutional economists such as F. Knight, J.R. Commons, C. Barnard, R. Coase, J.M. Buchanan, K.J. Arrow, O. Williamson, Davis and L.D. North, D.C. North and J. Knight. Transaction costs are minimized in the contracts economy where contract are made between parties and property rights are allocated. The "visible hand" approach, used in institutional regulations and institutional change discussion by D North, called as "invisible hand" metaphor of mainstream economics in Aoki's institutional game theory. In M. Aoki's approach ${ }^{5}$ (2001) the process of institutional change of economic system works as a self-adjusting process through invisible hand metaphor the same as in the works of D. Hume, C. Menger. F.A. Hayek, R.R. Nelson, S.G. Ninth, M. Kirzner, D. Lewis,

M. Aoki claims that (2001: 5) institutional problems are discussed in the context of game theory of mainstream economics. On the basis of institutional game theory, Nash equilibrium is the balance situation in which institution stay unchanged within the current social order. Who are parties that prepared the policy set? What kind of cause a distribution? These are the basic query of Nash equilibrium in the institutional game theory. In economics, shape of institutional regulations is also important as much as the process of institutional change. In accordance with mainstream economics approach, rules limit set of individual preferences in market game. However, in North's approach, institutions are "the rules of the game" in society or formal rules. In social life, the rules that shape human relations should always be regulated and renewed. 
A. Scott, R. Axelrod, K. and A. Grief (1998).In this sense, there is no place for transaction costs in the discussion of institutional change within institutional in game theory of economies.

In institutional game theory, transaction costs of the system can be ignored assuming all actors as rational actors with full knowledge. In Richter's approach (2005) institutional regulations and change processes are discussed in different contexts both in game theory in economics and in political economy and institutionalism debate in sociology. As believed by A. Grief (2001), history of economics is defined as "self-strengthening institutionalism" in size in the formal game theory. In this way, the mathematical background of spontaneous order of economics is prepared. In accordance with game theorists such as Schott (1981), Greif (2001) and Aoki (2001), social beliefs are shared among all actors in institutional game. This is a self-sustaining game. In Economics institutional change is provided by invisible hand. The expectations of actors about other actors are important in the game theory.

Unlike the NIE approach, social phenomena are explained within informal and formal theory. D. North states that social consensus is a harmonic situation in the institutional game approach. However, Nash equilibrium can also be a catastrophic situation. North's economic history analysis is operated by contracts that provide social efficiency. Institutional change in economic and political organization is provided by "visible hand" through contracts reducing transaction costs.

As maintained by Olson (1984), institutional aspect of the problem of unemployment is open to lead interest groups who get annuity from this problem. Unemployment phenomenon in the market creates new annuity channel among pressure groups such as employers, employer and labor unions, workplace representatives and company managers agreeing on personal interests. In a sense, unemployment is a Nash equilibrium state. In this equilibrium level, unemployment gets permanent status in the market as a bad equilibrium state unless political parties, trade unions, labor unions, media and labor laws take a different action plan. Unemployment gets institutionalized. Developing strategies, which produce institutional solutions in contracts and reduce transaction costs in market operations through the contexts of Williamson and North instead of a game equilibrium, provides high social benefits to the system. In the NIE approach, this situation refers to the "visible hand" approach in economics.

\section{Institutional Development Institutional Change Process}

Ensuring human motivation in market relations during the development process is the first and most difficult step in the processes of institutional change. It requires a long time. Human motivation is the determining factor of development in the formation of the social structure and the construction of the social order (Azfar, 2002). Adherence of motivation channel providing social structure and development to administrative and technical structure, cultural norms is important. In social life, the institutional changes skills 
must be acquired in terms of legal and political aspects. The acquisition of human motivation and social structure change process depends on the institutional experience gained by person in individual and social sphere. The development process among all stakeholders; the individuality of consciousness taking into account the other's welfare, the civic consciousness taking into account the other's welfare, citizenship consciousness with participation in the political system and the voting rights, consciousness of political economy consisting of ethnic differentiation and income inequality awareness and business consciousness with occupational class and differentiation should be placed in social change.

In the approaches of North and Richter, organizational decision-making units, entrepreneurs, the agents of institutional change processes and players play a great role in modelling of change and governance. The real source of the process of change is the opportunities perceived by entrepreneurs. Institutional change process is provided through the exogenous variables as policy and technology, while social learning is performed by the endogenous variables covering the skills hidden in the individual's mental structure. Learning and talent is decisive in the construction of various mental models used by entrepreneur to resolve the institutional environment. Institutional change usually occurs as external change and endogenous learning process together. The featured elements of the institutional environment in Williamson's approach are called as institutional components in Richter's works. The construction of legal structure of norms and customs to the stages of informal institutions is similar to Williamson's stages. Williamson in addition to Richter correlates positive political theory with economic development performance.

Institutions are the determining factor of the economic performance and efficient distribution. Institutions shape the political structure of the system, the rules of law and the borders of social elites. Institutions play a significant role in ensuring equality of opportunity in the establishment of property rights, while searching for solutions in social conflicts (Acemoğlu, 2003). In Acemoğlu, Europe's institutional history is the history of the struggle of political elites in the distribution of resources being as the pressure groups. Europe's development process, experiences the annuity transfer process of social elites who obtained political power in the colonial order caused by institutions. This process refers to the institutional order established in colonial states by political and economic elites. Acemoğlu refers to development process in political economy as a social experience, D. North called this process as experience gained with social learning.

As per Acemoğlu (2002), institutional structures in Europe vary based on geographical features of the colonial states. History of civilization is the history of welfare of the colonialist European nations in the coldest north of the world. Failure of institutions to catch a comprehensive growth rate was observed in economics based on exploitation system, while exploitative economies did not support the creative destruction process. Exploitative growth has been a driving force for central political institutions (Acemoglu \& Robinson, 2012). On the other hand, European colonies have led to the development of different institutional structures usually in tropical regions inhabited by indigenous peoples. 
Europe has spread imperialism in the tropical colonies by keeping the administrative and control power in the hand and providing the transfer of more resources to the colonies.

In the NIE approach, public choice is shaped by political institutions in social life. Political institutions are effective in the public's rational choice. As stated by Buchanan ve Tullock (1962), Mc Kelvey 1976, Riker (1981), Enelow and Hinic (1984), political institutions are intentional choices of the public. The frame determining the bureaucratic operations with the necessary constitutional amendments, legal procedures and the electoral system in the operation of legislative and executive bodies is prepared by the political institutions. In the NIE approach, Denzau and Mackay (1983), Shepsle and Weingast (1987) evaluate all macro policies such as welfare policies, budget discussions, technology policies and regulation within the rational choice perspective. Political institutions shape the institutional environment of the economy while affecting the performance of public policies.

In the NIE approach, it is the performance in the process of institutional transformation and social structure differences that make the globalization process different. O. Williamson states that performance increase in resource allocation process depends on the institutional development performance. R. Coase and O. Williamson's theory of transaction costs combines with North's heterodox concept and becomes the NIEH approach. Williamson thinks that the stages of the institutional environment build the stages of the process of institutionalization in market economy. Institutionalization process starts from the stage of informal rules and ends with optimization stage where efficiency is provided in the allocation of resources. Williamson firmly states that (2000: 597-599), institutionalization process in economy passes through four phases. At each phase, society goes through more advanced economic, political and legal environment.

The first phase is explained by social theory in Williamson's discussion of institutional change. In this process, institutional environment regulating the economic operation is governed by informal rules which consist of religion, social traditions and norms. The first stage is a spontaneous uneconomical period. In Richter's approach, social norms and customs are taken as the first stage of the institutionalization process similar to Williamson's. Norms and customs functioning as formal and tacit rules in social life are compared to collaborative Nash equilibrium (Shechelling, (1960). Schotters believes that (1981), social customs, the reconciliation of individuals in life, are social institutions influencing behavior. There are social customs at the background of contracts between parties. Ellickson considers that (1991) norms that regulate social life are more effective than the decision-making process. Community norms are customary laws.

The second phase is the construction of property rights. Williamson regards property rights as the second phase of institutionalization of the economy. The institutional environment, which provides the bureaucratic scheme, the allocation of property rights, the functioning of the legislative and executive organs in market games, is realized by overcoming of informal constraints and setting formal rules. At this stage, economic performance increase and legal institutionalization level are expected to act in co-ordination 
in the development process. At the stage of positive political theory, power is shared between different groups, and legal and bureaucratic functions of the management are determined. In the construction phase of property rights political institutions of the system are formed. The citizenship rights are acquired in the face of the state. Commercial bourgeoisie is created and property rights are institutionalized.

In terms of North and Olson, second phase of institutional environment is the democratization process. Positive political theory is a process securing and increasing economic performance. Richter like Williamson sees the process of legal environment and allocation of property rights as the conditions improving the performance of institutional environment. In the NIE approach in accordance to liberal approach, legal structure / environment and property rights are the key elements of institutional environment shaping economic life. In market societies legislative environment and property rights are born outside the central and legal tradition. The civil action produced by individuals is a product of tradition. In the institutionalization process, while discussing the legal environment in terms of property rights, Llewellyn (1931) and MacNeil (1974) analyze legal environment in terms of contract law in addition to property rights. (Alchian 1961) Demsetz (1967) and Pejovich Furubotn (1972, 1974), De Alessi (1980) and Barzel (1989). The organization of legal terms economic and political institutions in the system is a process that increases development performance.

The third phase is the construction of governance structure. As per Williamson third phase is the change process related to the governance structure and the gameplay of the game. In this process, contracts are made in market relations and transaction costs of economies are operated. By D. North, this process is the stage when the optimal form of governance for each procedure type is preferred and transaction costs are minimized in terms of organization. At this stage, social change removed from the intellectual dimension through legal institutions and converted into law targeting economic efficiency. Democratic institutional structuring is completed; corruption problem is resolved in the system.

Williamson supposes that transaction cost economies are formed and there is economic and political institutionalization experience reducing market transaction costs in the third stage. The third phase of institutional change is the building process of finance, monetary and trade policies and where the governance problems are discussed in presidential system or parliamentary system within positive political theory. In this process, the costs of some organizations as firms are reduced through transaction costs economy. In the third stage where the governance structure of the system is constructed, the pressure groups who gained benefit from existing governance patterns, resistance against the change of markets and among bureaucracy.

The fourth phase is efficiency in resource allocation. R. Coase and O. Williamson's theory of transaction costs combines with North's heterodox concept and becomes the NIEH approach. Institutionalization process starts from the stage of informal rules and ends with optimization stage where efficiency is provided in the allocation of 
resources. Williamson holds the opinion that (2000: 597-599), institutionalization process in economy passes through four phases. At each phase, society goes through more advanced economic, political and legal environment. Effective resource allocation creates a higher equilibrium in economy: national income and employment levels through price mechanism and incentive system. The institutional dimension of development is important in the globalization process. Globalization is a process with economic, legal and sociological basis.

Williamson brings the relationship of effective institutional change and high economic performance in economics by moving the stages of the institutional environment to development literature in the institutionalization process. As maintained by Azfar, the demographic allocation of human capital is a compulsory variable that distinguishes institutional change process. Social capital that affects economic performance is an important part of social structure. Social structure is a production factor as physical and human capital. For example, increase in the participation rate of the female labor force in public and private sectors reduce the tendency of corruption. The relationship between political processes and conditions that affect institutional changes performance is discussed within the positive political theory as social understanding and institutional environment components in the approaches of D. North and Richter respectively. In North's approach, institutional environment is used in a special terminology as "mental models", "ideology", "culture", "political institutions" and "governance structure". Richter states that (2003, 1124), social cognition, norms and social customs, legislation, property rights, historical performance of the economy, history of development and development level of political institutions are the components of the institutional environment in the system.

\section{Conclusion}

For the last thirty years, there's been no answer to the problem of how to ensure the efficiency target of market economy in the countries of Asia, Latin America, Middle East and Sub-Saharan Africa, and in emerging markets and developed countries of the world; and in all liberal and anti-globalization circles. Today the same problem evolves and flourishes at the heart of global recession debates. The construction of the international monetary and financial system and the governance of the process of all institutional changes and regulations in money, goods and financial systems are priority problems of economics science that needs to be solved.

Institutionalization debate in economics adds market behaviors neglected by mainstream economics and the context covering the institutional effects to economics and it creates opportunity for economics to produce policy regulating economic and political system. The reciprocal relationship among economic, political and legal institutions in social life is decisive in the reacquisition of the context left to political science, sociology and even to a politician by the science of economics. The processes of distribution and decisionmaking, which are not in the main problematic of mainstream theory, as well as the power network are governance institutions affecting economic institutions, theory and the performance of politics. 
The economic theory must reproduce institutions formally and informally in public and private organizational network particularly government being in the first place. On the other hand, a new theory should be developed analyzing behavioral institutions such as profit, competition, consumption, and savings in economic life as well as social cognitive processes such as ideology, culture, social learning, social representation, mental models. Science of economics should regulate institutional structure to deepen economic thought; and at the same time economic thought must demonstrate policy performance to change the institutional structure.

Mainstream economics while transferring the role of institutional regulation and supervision to invisible hand metaphor, it also passes the role of determining the social context of the global system as well as governance domain. Sliding from the hands of economics, economy and political power are producing new distribution mechanisms and opportunities in nation-state's legal or illegal organizational charts, in global markets, and among global players and political actors. Liberal theory is not able to get the theoretical support from economics to reproduce institutional dynamics of the system. The economic and political institutions of liberal system are institutionalized by producing informal structures. Post 1980 events, such as the transition process of Eastern Bloc countries and China to a market economy, the events called The Arab Spring in Middle East countries, are significant in terms of development and institutional changes performance, but at the same time, they are the developments of concern.

The changes and regulations process transferred to the price mechanism through invisible hand metaphor in the mainstream economics is discussed by visible hand logic in the NIE approach by property rights, transaction costs, and contracts economy approach. Institutional environment is built with the help of institutions guaranteeing the terms of the contract and property rights in the NIE, R. Coase and O. Williamson's approaches. Accordingly, in this type of organizational institutions, administrative and legal context of the environment that reduces transaction costs become the agenda of economics. In a similar way, administrative and legal context, which envisions effectiveness by lowering transaction costs and defines the boundary between behavioral institutions of economics and politics and government, is discussed in D. North and O. Williamson's approaches. The process which has reduced transaction costs and increased the development process through visible hand in the system adds a new dimension to the development debate.

It appears that, there is a chance for the birth of a critical realist, pluralist and multicultural method covering the relationship of economic theory, economic institutions and the institutionalization, including the social context of the economy. Economics, legal and social psychology perspective offer a different content in the analysis of the economy political behavior of the human. In the mainstream economics, the mutual relationship between intellectual and behavioral institutions of economics and economic institution is detached by formalistic method. The process of institutionalization, which is not able to reproduce each other theoretically and institutionally, produces informal relations that has not been foreseen by rationality in the mainstream economics which counts formalism the 
one and only method. In this process, while legitimate and formal borders of science, intelligence and law tighten, the system quickly evolves into unscientific, irrational, illegitimate and informal space.

Within the concept of institution, the relationship of social psychology with the concepts such as social cognition, social representations and mental models; the relationship of law with the concepts of property rights, contract economies and the relationship of governance and political science with the concept of governance structure in the NIE approach are all excluded from the scope and responsibility of the mainstream-theory (Orhan, 2016, 2016b, 2016c). This social context provides the economic theory with a methodological perspective that reproduces itself in the economic institutions in an organizational and behavioral sense. By this way, economic theory and institution evolve with a methodological pluralist approach. Economics' distanciation from passion of formalism, methodological individualist and monistic approach; and becoming a science operating with multicultural, complex dynamics changes the development perspective in the global system. All theories opened to cross cultural context through pluralist methodology increase the development performance of economic policy. In this manner, the agenda of different approaches providing the evolution of economic institutions and economic theory through a pluralistic methodology is very important in the building of the lost political economy of economics.

\section{References}

Acemoğlu, D.S. \& J. Robinson (2002), "Reversal of Furtune Geography and Institutions in Making of Modern Income Distribution”, Quarterly Journal of Economics, 117, 1231-1294.

Acemoğlu, D.S. \& J. Robinson \& Y. Thaicharoen (2003), "Institutional Causes, Macroeconomic Syptoms. Volatility, Crises and Growth”, Journal of Monetary Economics, 50, 49-123.

Acemoğlu, D.S. \& J. Robinson (2012), Ulusların Düşüşü, Güç Zenginlik ve Yoksulluğun Kökenleri, Çev. F.R. Velioğlu, Doğan Kitapevi.

Aoki, M. (2001), Toward a Comparative Institutional Analyisis, Cambridge, MA: MIT Pres.

Azfar, O. (2002), "The NIE Approach to Economic Development: An Analytical Primer", Forum 1. Introductory Session on NIE, The Irish Centre, Departmant of Economics, Univercity of Maryland, Collage Park, January 11.

Brunner, K. (1992), “Ronald Coase: Old Fashioned Schooler”, Scandinavian Journal of Economics, 94(1), Cambridge, MA,

Cheung, S. (1970), "The Structure of A Contract and Theory of A Non Exclusive Resource", Journal of Law and Economics, XIII (1970), 49-70.

Coase, R.H. (1937), “The Nature of the Firm”, Economica, New Series, 4(16), 386-405.

Coase, R.H. (1984), "The New Institutional Economics”, Journal of Institutional and Theorical Economics, 140, 229-231.

Coase, R.H. (1994), Essays on Economics and Economists, The University of Chicago Press.

Coase, R.H. (1960), "The Problem of Social Cost”, Journal of Law and Economics, 3, 1-44.

Coase, R.H. (1988), The Firm, The Market and The Law, Chicago: University of Chicago Press. 
Coase R.H. (1992), “The Institutional Structure of Production”, The American Economic Review, 82(4), 713-719.

Cornes, R. \& T. Sandler (1986), The Theory of Externalities, Cambridge Unv. Press.

Cohen, J.M. (1996), "Ethnicity, Foreign Aid and Economic Growth in Sub Saharam Africa: The Case of Kenya", HIID Development Discussion Paper, No. 520.

Davis, L.E. \& D.C. North (1971), Institutional Change and American Economic Growth, Cambridge University Press, Chambridge.

De Alessi, L. (1987), "Nature and Methodological Foundations of Some Recent Extensions of Economic Theory in Economic Imperialism", in: Economic Imperialism: The Economic Approach Applied Outside the Field of Economics, eds. G. Radnitzky \& P. Bernholz, New York: Paragon House, 51-76.

De Alessi, L. (1993), "Property Rights, Transaction Costs and X Efficiency, An Essay in Economic Theory", American Economic Review, 3(1), 64-81.

Denzau, A. \& D.C. North (1994), 'Shared Mental Models: Ideologies and Institutions', Kyklos, 47, 3-31.

Demsetz, H. (1964), "The Exchange and Enforcement of Property Rights", American Economic Review, Paper and Proceeding, 57, 11-26.

Demsetz, H. (1967), “Toward A Theory of Property Rights", American Economic Review, Paper and Proceeding, 57, 347-359.

Dequech, D. (2002), "Demarcation between The Old and The New Institutional Economics: Recent Complications", JEI Journal of Economic Issues, 36(2), 565-72.

Eggertsson, T. (1990), Economic Behavior and Institution, Chambridge University Press, MA.

Frubotn, E. \& S. Pejovich (1972), "The Economics of Property Rights: A Survey of Recent Literature", Journal of Economic Literature, 1137-1401.

Gonick, L.S. \& R.M. Rosh (1988), "The Structural Constraints of The World-Economy on National Political Development”, Comparative Political Studies, 21, 171-199.

Grief, A. (2005), Institutions and The Path to the Modern Economy: Lessons from Medievel Trade, Political Economy of Institutions and Decicions, Cambridge, Grunchy (1947).

Hayek, F.A. (1967), Studies in Philosophy, Politics, and Economics, Chicago: University of Chicago Press.

Hayek, F.A. (1973), Law, Legislation, and Liberty: Rules and Order, Vol. 1, Chicago: University of Chicago Press.

McKean, R. (1970), "Products Liability Implications of Some Changing Property Rights", Quarterly Journal of Economics, 84(4), 611-626.

McKean, R. (1972), "Property Rights Within Gowernment and Devices to Increase Govermental Efficiency, Southern Economic Journal, 39(2), 177-186.

Klein, P.G. (2000), "New Institutional Economics", in: Encyclopedia of Law and Economics, Eds. B. Boukeart \& G de Geest, Edward Elgar, Cheltenham, Glos9, 456-489.

Langlois, R.N. (1989), “The New Institutional Economics: an Introductory Essay”, in: Langlois, R.H. (Ed.), Economics as a Process, Cambridge, New York, Melbourne, 1-25.

North, D.C. (1971), "Institutional Change and Economic Growth", Journal of Economic History, 31, $118-125$ 
North, D.C. (1981), "Structure and Change in Economic History", New York, Journal of Economic Literature, 16, 963-978.

North, D.C. (1990), Institutions, Institutional Change and Economic Performance, Cambridge: Cambridge University Pres.

North, D.C. (1991), "Institutions", Journal of Economic Perspectives, 5: 97-112.

North, D.C. (1995a), “The New Institutional Economics and Third World Development”, in: Harriss, Hunter and Lewis, 17-26.

North, D.C. (1995b), "The Adam Smith Address: Economic Theory in a Dynamic Economic World", Business Economics, 30, 7-12.

North, D.C. (1984), “Government and The Cost of Exchange”, Journal of Economic History, 44, 255-264.

North D.C. \& W. Summerhill \& W. Barry (2000), "Order, Disorder and Economic Change", in: Governing for Prosperity, Edited by Bruce Bueno de Mesquita \& Hilton Root, New Haven, CO: Yale University Press.

Orhan, S.S. (2011), "İktisatta Yeni Yaklaşımlar", ed. Ercan Eren \& Metin Sarfati, içinde: Yerleşik İktisatta Heterodoksi: Yeni Kurumsal İktisat, İletişim Yay., 59-87.

Orhan, S.S. (2016a), "In the New Institutional Economics Approach R. Coase and Law, D. North and Social Psychology Context: Pluralist Approach Opportunities in Economics", Sosyoekonomi, 24(28), 189-208.

Orhan, S.S. (2016b), Türkiye'de Kuramsal Olarak İktisadi Düşünce: İktisat Kurumunun Modernist Sosyal Bilişi, Otoriter Sosyal Temsiller ve Liberal Retorik, İletişim Yay. Basım Aşaması.

Orhan, S.S. (2016c), "Modern Makro Uzlaşının Kayıp Ekonomi Politiği: Yerleşik Formalist, Yerleşik Kurumsal ve Yerleşik Politik Uzlaşı”, Sosyoekonomi, 24(27), 139-160.

Parada, J. (2001), “Original Institution Economics: A Theory for $21^{\text {st }}$ Century", Oeconomicus, V, Fall 2001, 46-60.

Parada, J. (2002), "Original Institutional Economics and New Institutional Economics: Revisiting the Bridges (Or the Divide)", Oeconomicus, VI, Fall 2002.

Richter, R. (2005), "The New Institutional Economics - Its Start, Its Meaning, Its Prospects 1", Revised 9 November, 2005. An Earlier Version appeared in: The European Business Organization Law Review (EBOR), 6(2), 161-200.

Rutheford, M. (1995), “The Old and The New Institutionalism: Can Bridges Be Built?”, Journal of Economic Issues, 29, 443-451.

Umbeck, J. (1981), “A Theory of Formation and Initial Distribution of Property Might Makes Rights”, Economic Inquiry Journal, 19(1), 38-59.

Williamson, O.E. (1975), The Mechanism of Governance, New York, NY. Oxford Univercity Pres.

Williamson, O.E. (1985), The Economic Institution of Capitalism, New York et al: Free Press.

Williamson, O.E. (2000), “The New Institutional Economics: Taking Stock, Looking Ahead", Journal of Economic Literature, 38, 595-613.

Veblen, T. (1898a), The Theory of Leisure Class. Theory of the Leisure Class: An Economic Study of Institutions, New Brunswick, New Jersey: Transaction Publishers, 1989 [1899].

Veblen, T. (1898b), "Why is Economics not An Evolutionary Science?", The Quarterly Journal of Economics, 12(4), 373-397. 